\title{
Determination of banana fruit susceptibility to post-harvest diseases: wound anthracnose, quiescent anthracnose and crown rot
}

\author{
Luc de Lapeyre de Bellaire ${ }^{1 *}$, Marc Chillet $^{2}$, Yolande Chilin-Charles $^{3}$
}

${ }^{1}$ CIRAD - Persyst, UPR Systèmes bananes et ananas, CARBAP, BP 832, Douala, Cameroon

luc.de_lapeyre@cirad.fr

${ }^{2}$ CIRAD, Persyst, UMR Qualisud, Fac. Farm., Univ. Sao Paulo, avenida Lineu Prestes, 580, Bloco 14 05508900n Sao Paulo, SP, Brasil marc.chillet@cirad.fr

${ }^{3}$ CIRAD - Bios, UPR Multiplication végétative, Station de Neufchâteau, 97130, Capesterre Belle-Eau, Guadeloupe, France yolande.chilin-charles@cirad.fr

* Correspondence and reprints

Fruits, 2008, vol. 63, p. 183-186 (C) 2008 Cirad/EDP Sciences All rights reserved DOI: 10.1051/fruits:2008009 www.fruits-journal.org

Determination of banana fruit susceptibility to post-harvest diseases: wound anthracnose, quiescent anthracnose and crown rot.

Abstract - Introduction. This protocol aims at (a) evaluating the resistance to post-harvest diseases within different genotypes of bananas, and (b) comparing different origins of bananas (geographic origin, physiological stage, etc.) for their susceptibility to post-harvest diseases. The principle, key advantages, starting plant material, time required and expected results are presented. Materials and methods. Materials required and details of the twelve steps of the protocol (fruit sampling and inoculum preparation, wound anthracnose resistance study, quiescent anthracnose resistance study and crown-rot resistance study) are described. Results. Typical symptoms of the different diseases are obtained after artificial inoculation.

France (Guadeloupe) / Musa sp. / Colletotrichum musae / disease resistance/ methods

Détermination de la sensibilité des bananes aux maladies de conservation : anthracnose de blessure, anthracnose quiescente, pourriture de la couronne.

Résumé - Introduction. Ce protocole vise (a) à évaluer la résistance aux maladies de conservation pour différents génotypes de bananiers, (b) à comparer différentes origines de bananes (origine géographique, stade physiologique, etc.) vis-à-vis de leur sensibilité aux maladies de conservation. Le principe, les principaux avantages, le matériel végétal de départ, le temps nécessaire et les résultats attendus de la méthode sont présentés. Matériel et méthodes. Le matériel nécessaire et le détail des douze étapes de réalisation du protocole (prélèvement de fruits et préparation d'inoculum, étude de résistance à l'anthracnose de blessure, étude de la résistance à l'anthracnose quiescente et étude de résistance à la pourriture de couronne) sont décrits. Résultats. Des symptômes types des différentes maladies sont obtenus après inoculation artificielle.

France (Guadeloupe) / Musa sp. / Colletotrichum musae / résistance aux maladies / méthode

\section{Introduction}

\section{Application}

This protocol aims at:

- evaluating the resistance to post-harvest diseases within different genotypes of bananas,

- comparing different origins of bananas (geographic origin, physiological stage, etc.) for their susceptibility to post-harvest diseases.

\section{Principle}

The principle of the method is to simulate the conditions of natural infections. The evaluation of the resistance is based on artificial inoculation with the pathogen involved in the various post-harvest diseases.

For wound anthracnose and quiescent anthracnose, that should be considered as two different post-harvest diseases, the pathogen is Colletotrichum musae [1]. For crown rot, the most common pathogens 
implied are Colletotrichum musae, Fusarium moniliforme, Fusarium pallidoroseum, Botryodiplodia theobromae and Cephalosporium spp. [2-5]. However, Colletotrichum musae is the most pathogenic species and will be used for these studies.

\section{Key advantages}

While this method is time-consuming and more fastidious than the observation of natural infections, its key advantage lies in its accuracy and reliability. Under natural contamination, the development of post-harvest diseases is too erratic.

\section{Starting material}

The method requires mature, freshly harvested bananas and fungal cultures of the different pathogens involved in the postharvest diseases.

\section{Time estimation}

For wound anthracnose, the time required is $15 \mathrm{~min}$ for fruit sampling; $20 \mathrm{~min}$ for fruit inoculation; $15 \mathrm{~min}$ for fruit wounding; $10 \mathrm{~min}$ for disease assessment.

For quiescent anthracnose: $15 \mathrm{~min}$ for fruit sampling; $20 \mathrm{~min}$ for fruit inoculation; $10 \mathrm{~min}$ for disease assessment.

For crown rot: $15 \mathrm{~min}$ for fruit sampling; $20 \mathrm{~min}$ for fruit inoculation; $15 \mathrm{~min}$ for disease assessment.

\section{Expected results}

We obtain (a) for wound anthracnose, the surface of lesion; (b) for quiescent anthracnose, the surface of lesion; (c) for crown rot, the internal surface of rot (ICR).

\section{Materials and methods}

\section{Laboratory materials}

The protocol requires:

- agar plates with Mathur's medium $\left(\mathrm{MgSO}_{4}\right.$ $7 \mathrm{H}_{2} \mathrm{O} 2.5 \mathrm{~g}$; peptone $1 \mathrm{~g}$; yeast extract $1 \mathrm{~g}$; saccharine $10 \mathrm{~g}$; agar $15 \mathrm{~g}$; water $1 \mathrm{~L}$ ),
- a Malassez counting cell,

- sterile distilled water,

- a microscope,

$-50 \%$ alcohol,

- a computerized penetrometer with a rounded probe (1-cm diameter),

- a controlled environment cabinet regulated at $13{ }^{\circ} \mathrm{C}$,

- a controlled environment cabinet regulated at $20{ }^{\circ} \mathrm{C}$,

- a controlled environment cabinet regulated at $25{ }^{\circ} \mathrm{C}$.

\section{Protocol}

\section{Fruit sampling and inoculum preparation}

- Step 1. Fruit sampling

- In order to minimize the effect of natural infections that might occur in the field, floral remnants should be removed early (when fruits are in a horizontal position), and bunches should be covered with a plastic sleeve just after [1].

- In order to minimize within-bunch variability, use bananas of the third hand (eventually also those of the second hand).

- Harvest bananas at the same physiological age corresponding to $75 \%$ of the thermal sum that this genotype would reach at the "first yellow-fruit stage". For Cavendish bananas, $900{ }^{\circ} \mathrm{C}$-days is the thermal sum recommended. This thermal sum will differ according to the different genotypes of bananas studied.

- The optimum situation is to harvest 20 bunches per cultivar or treatment, each bunch being then considered as a replicate. When it is not possible to harvest 20 bunches at the same time (various cultivars), a minimum of 10 bunches should be harvested on different dates and compared in each experiment with the cultivar Grande Naine as reference.

- Step 2. Inoculum preparation

- Inoculate Mathur's medium plates with a small plug from a fungal colony of Colletotricum musae. Fungal cultures should be monosporic and should not be sub-cultured more than 5 times. 
Note: initiate new cultures from frozen conidial suspensions conserved at $-80^{\circ} \mathrm{C}$ in 30\% glycerin.

- Store fungal cultures at $25^{\circ} \mathrm{C}$ for $10 \mathrm{~d}$.

- After $10 \mathrm{~d}$ of incubation, flow the fungal cultures with distilled sterile water.

- Filtrate the conidial suspension through a 35- $\mu \mathrm{m}$ sieve.

- Calibrate the conidial suspension to $\left(10^{6}\right.$ and $10^{4}$ ) conidia $\cdot \mathrm{mL}^{-1}$ using the Malassez counting cell.

\section{Wound anthracnose resistance study}

\section{- Step 3}

Sample a fruit on the external row of the third hand of each bunch (ideally 20 per treatment or cultivar).

- Step 4

On one of the side faces of the fruit, deposit $25 \mu \mathrm{L}$ of the Colletotricum musae conidial suspension calibrated to $10^{6} \mathrm{conidia} \cdot \mathrm{mL}^{-1}$ (locate inoculation area with a felt pen). Once the droplet is dry, cover the inoculated area with a humidified swab. Wrap with plastic to maintain humidity. Store the fruits at $25^{\circ} \mathrm{C}$ for $48 \mathrm{~h}$.

\section{- Step 5}

Bruise the fruit at the place where inoculum was deposited. Crushing is done with a computerized penetrometer equipped with a rounded probe. The speed of the probe is $5 \mathrm{~mm} \cdot \mathrm{s}^{-1}$ and a $5-\mathrm{mm}$ compression is exerted on the fruit for $4 \mathrm{~s}$. Store the fruits at $20^{\circ} \mathrm{C}$.

\section{- Step 6}

Ten days after inoculation, start measuring the surface of the lesions, assuming that the lesion is elliptical [length $\times$ width $\times(\Pi / 4)$ ], and repeat it every $2-3 \mathrm{~d}$ until fruits are ripe. For Cavendish bananas, another possibility is to store the fruits for $10 \mathrm{~d}$ at $13^{\circ} \mathrm{C}, 10 \mathrm{~d}$ at $20^{\circ} \mathrm{C}$, and then measure the surface of the lesions.

\section{Quiescent anthracnose resistance study}

\section{- Step 7}

Sample as described in step 3 and inoculate the Colletotricum musae conidial suspension as described in step 4 .
- Step 8

Store the fruits at $20^{\circ} \mathrm{C}$.

- Step 9

Ten days after inoculation, start measuring anthracnose lesions as in step 6.

\section{Crown-rot resistance study}

- Step 10

Sample a cluster of four fruits on the third hand of each bunch (ideally 20 per treatment or cultivar).

- Step 11

For each cluster, remove a thin slice of crown on all sections. Wait $30 \mathrm{~min}$ for latex flow and sterilize the crown by dipping in $50 \%$ ethanol. Wait at least $30 \mathrm{~min}$ for the alcohol to dry and deposit $50 \mu \mathrm{L}$ of the conidial suspension, calibrated to $10^{4}$ conidia $\mathrm{mL}^{-1}$, on the upper face of the crown. Cover this droplet with a $1-\mathrm{cm}^{2}$ paper filter and place the fruits at $25^{\circ} \mathrm{C}$ for $3 \mathrm{~h}$ before storage at $13^{\circ} \mathrm{C}$.

- Step 12

Thirteen days after storage at $13{ }^{\circ} \mathrm{C}$, split the cluster crown into two parts, and measure the internal crown rot surface (ICR).

\section{Troubleshooting}

- Step 13

Very few failures should happen; nevertheless, if the fungal cultures are sub-cultured for a long period ( $>5$ subcultures), the strains might lose their pathogenicity: regularly initiate new fungal cultures from frozen conidial suspensions.

\section{Typical results obtained}

Typical symptoms of wound anthracnose (figure 1) and crown rot (figure 2) are obtained after artificial inoculation.

\section{References}

[1] Meredith D.S., Studies on Gloeosporium musarum Cke and Massee causing storage 
Figure 1.

Wound anthracnose assessed on Cavendish bananas.

Results on bananas stored for $10 \mathrm{~d}$ at $13^{\circ} \mathrm{C}$ and showing young brown lesions starting from the inoculated area.

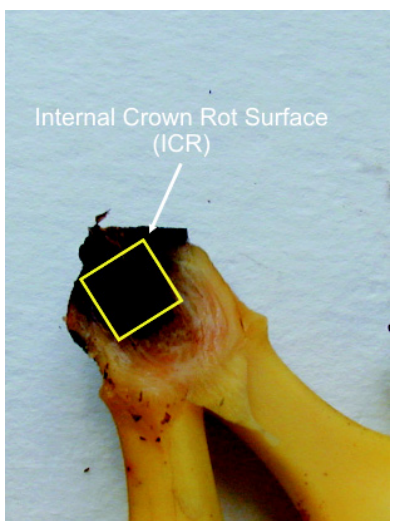

Figure 2.

Crown rot of bananas assessed $13 \mathrm{~d}$ after storage.

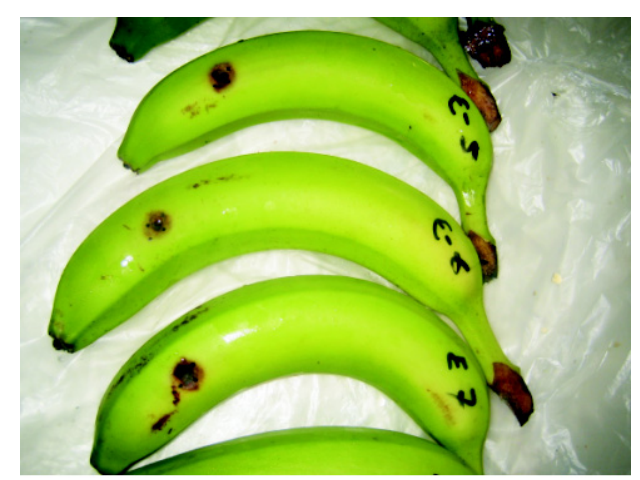

rots of Jamaican bananas. I. Anthracnose and its chemical control, Ann. Appl. Biol. 48 (1960) 279-290.

[2] Johanson A., Blasquez B., Fungi associated with banana crown-rot on field-packed fruit from the Windward Islands and assessment of their sensitivity to the fungicides thiabendazole, prochloraz, and imazalil, Crop Prot. 11 (1992) 79-83.
[3] Lukezic F.L., Kaiser W.J., Martinez M.M., The incidence of crown rot of boxed bananas in relation to microbial populations of the crown tissues, Can. J. Bot. 45 (1967) 413421.

[4] Marin D.H., Sutton T.B., Blankenship S.M., Swallow W.H., Pathogenicity of fungi associated with crown rot of bananas in Latin America on Grande Naine and diseaseresistant hybrid bananas, Plant Dis. 80 (1996) 525-528.

[5] Wallbridge A., Fungi associated with crownrot disease of boxed bananas from the Windward Islands during a two year survey, Trans. Br. Mycol. Soc. 77 (1981) 567-577.

[6] de Lapeyre de Bellaire L., Chillet M., Dubois C., Mourichon X., Importance of different sources of inoculum and dispersal methods of conidia of Colletotrichum musae, the causal agent of banana anthracnose, for fruit contamination, Plant Pathol. 49 (2000) 782790. 